\title{
ゴム状物質の大変形の一つの解析法*
}

$$
\begin{array}{lllll}
\text { 佐 藤 } & \text { 良** } & \text { 桜 } \text { 井 } \text { 正 幸** } \\
\text { 水 野 高 秀** } & \text { 堀 内 } \text { 健 二** }
\end{array}
$$

A Method of Analyzing Large Deformation Behavior of Rubber-Like Materials

by

\author{
Yoshiyasu Sato, Masayuki SakuraI, Takahide Mrzuno and Kenji Horiuchi \\ (Faculty of Textile Science and Technology, Shinshu University, Ueda)
}

\begin{abstract}
A stress-strain relation, $f=\left\{G-B(1-1 / \alpha)+C\left(\alpha^{2}-1\right)\right\}\left(\alpha-1 / \alpha^{2}\right)$, was used to analyse the large deformation behavior of styrene-butadiene rubber (SBR) with various concentrations of oil ranging from 0 to 40 PHR. In the above relation, $f$ denotes nominal stress at extension ratio $\alpha$, $G$ corresponds to rigidity, $B$ and $C$ are coefficients. The theoretical character of this relation will be discussed in another papers by one of the authors. The present results can be summarized as follows; The value of $G$ is proportional to the crosslink density $\nu_{e}$, but larger than those calculated from $\nu_{e} k T$. The value of $B$ is almost unaffected by $\nu_{e}$ and shows almost same tendencies as $G$ against oil concentration $v_{1}$ and strain rate $\dot{\varepsilon}$. The value of $C$ is about $1 / 100$ of those of $G$ and $B$, and had the maximum against $\nu_{e}$ and $\dot{\varepsilon}$.
\end{abstract}

(Received Jan. 16, 1973)

1 ま がき

これまでわれわれは，特異な逆 S 字状張力一伸度曲 線で象徽されるゴム状弾性を含む, ジム状粘弾性体の 多梯な变形举動を, 1 つの 3 パラメータ近似式 $f=$ $\left(A+B / \alpha+C \alpha^{2}\right)\left(\alpha-1 / \alpha^{2}\right)(1)$ て記速し，解析するこ とを目的としてきた. 上式で $f$ は初期断面皘当たりの 張力, $\alpha$ は伸度， $A, B, C$ はこの近似に括的俰数 を表わす．そして，(1)式を非平衡的な粘弾性挙動の記 述に用いるため, 保数 $A, B, C$ を時間, 温度, 配合

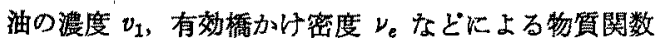
として, それら係数の時間，温度， $v_{1}$ 依存性を倹討し， その結果を報告した. (1)式は有限変形弾性論かっらの第 1近似式であるが, グリーンーリブリン粘弾性体の構 成方程式の第 1 近似式と形式的に同型であり，また石 原ら壮よび Wang-Guthの分子論亡す同型である。詳 しい性格にういて証著者の1人が別報で論しる予定で ある. 係数和一定の法則: $A+B+C=G$ (㓮性率) $k$ 上り，(1)式梳 $f=\left\{G-B(1-1 / \alpha)+C\left(\alpha^{2}-1\right)\right\}(\alpha-1 /$ $\left.\alpha^{2}\right)$ (2) となる. 小文では,これまでの非溶媒型油配合 試料の結果と比較するため, 溶媒型油配合試料を用い， 従来の $A, B, C$ 代㕫に，(2)式の $G ， B, C$ につ

* 原稿受理 昭和48年1月16日

** 正会 員 信州大学維学部 上田市常入
いて, その $\nu_{e}, v_{1}$, 時間俵存性, また破壞特性との間 連を検討した。な执，非溶媒型，溶媒型と異なる 2 種 の油の配合が，加硫 SBR の力学物性に及ぼす影響は， 1，2の性質を除く多くの現象で添注同様であった。 このことから，棌とんどすべての油の配合は同様な効 果をむつであろらと考党られる。

\section{2 実験}

\section{$2 \cdot 1$ 試料}

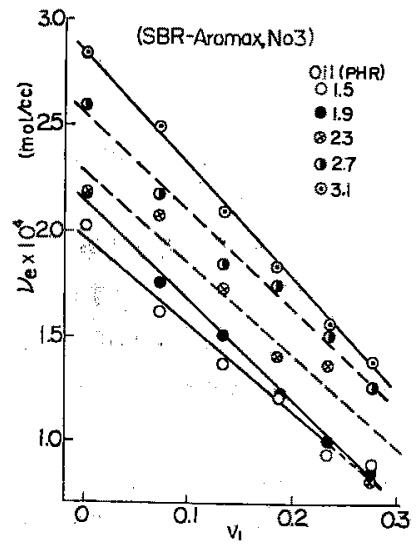

Fig. 1. Crosslink density $\nu_{e}$ of the samples as a function of oil concentration $v_{1}$. 

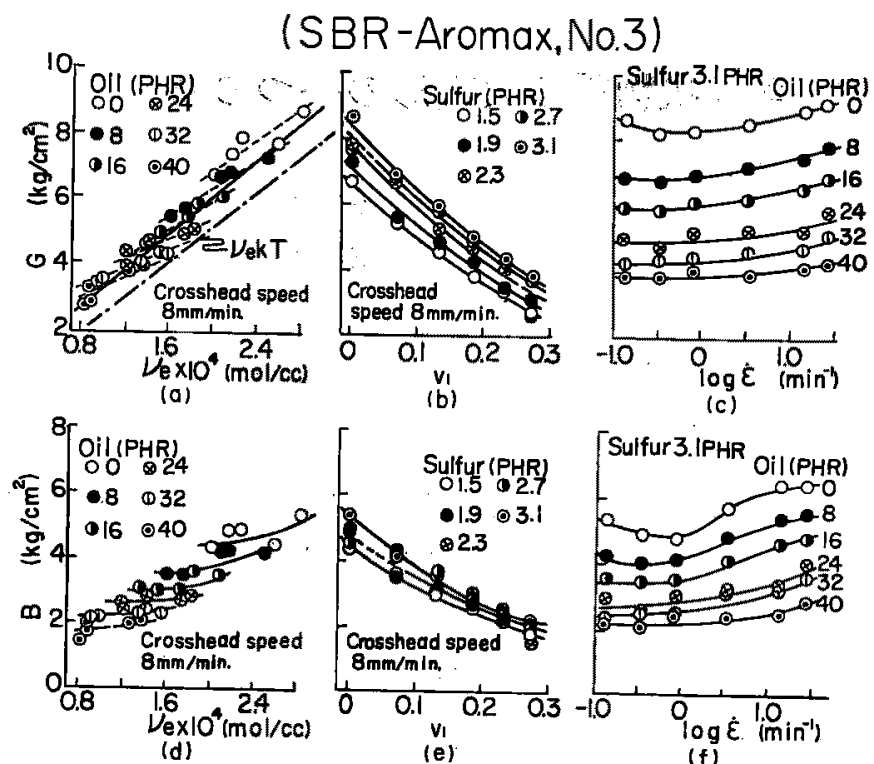

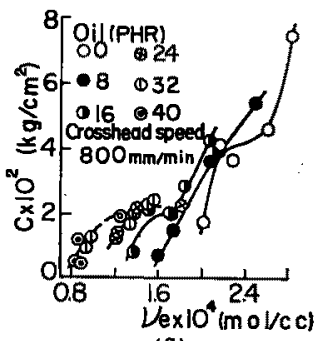

(9)

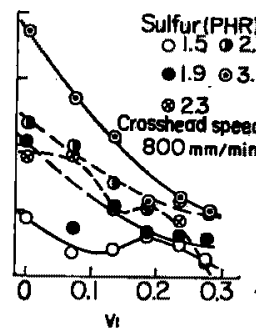

(h)

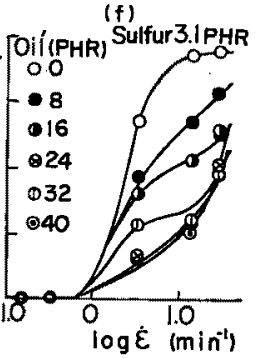

(i)

Fig. 2. An example of dependences of $G, B$ and $C$ on crosslink density $\nu_{e}$, oil concentration $v_{1}$ and strain rate $\dot{\varepsilon}$.

スチレソーブタジニンゴム（SBR 1502）に硫黄(S) と油を变量して配合した試料采を用いだ、油は芳香族 系の商品名 Aromax, No.3 で, SBR に対して溶媒 型といわれている。配合は非溶媒型油 (Circolight) 配合試料と同じであり，160`で 60 分加硫した。試料 の有効橋かけ密度 $\nu_{e}$ は，油の淟度 $v_{1}$ に対して直線的 に減少している (Fig. 1).עeは，試料中の油をつせ トンで抽出した後，ベンゼンによる膨潤法で求めだ.

\section{$2 \cdot 2$ 測定}

前報の ${ }^{2)} \mathrm{Circolight}$ 配合試料を用いた時と同一の条 件で定速引張試駼を行なった。

\section{3 結果招よび考察}

$3 \cdot 1 \underset{2}{G}, B, C$ の $\nu_{e}, v_{1}$, ひずみ速度安依存性 前報では，Circolight 配合試料について， $A, B$, $C の \mathrm{~S}$ 量， $v_{1}$, 主侤存性を報告したが，ここでは， $A$ の代わりに，より合理的な $G$ を用い，さらにS 量の代 わりに レ を用いて捡討した結果， $G ， B ， C$ の性格 がかなり明りょうになったようである。.Fig. 2 にG， $B, C の \nu_{e}, v_{1}, \dot{\varepsilon}$ 俵存性の 1 例を示した。非溶媒型 のCircolight 配合陚料についても，再検討の結果，
これらの倾向は同様であった，GとBの 対する傾向は㤬とんど同じであるが，その主な違いは， $G$ は見掛け上 $v_{1}$ によらず1本の直線とみられるが， $v_{1}$ による小直線群の集まりである。そして、1 1 本に見 えた直線より，小直線のこう配は小さく， $v_{1}$ の増加に つれて，小直線の位置が $\nu_{\mathrm{e}}$ の小さい方へ移動すると ともにそのこう配も小ざくなる.他方， $B$ は各 $v_{1}$ の 小直線のこう配がGのそれより小さく，ほとんどע。 に対して平行であるから，v1によらない1本の直線と みることはできない，見掛け上1本の $G$ の直線は， $\nu_{e} k T$ の計算直線に比べ，こ5配は汪とんぞ同じであ るが，切片が大きい，また，個個のデータについてみ ると，油量とS量が共に多い試料でちが小さい時，G の值は $\nu_{e} k T$ の值に近くなっている.したがって，G の $\nu_{e}^{k T}$ 加らのはずれは，からみ合いや 2 次凝集のは ずれ，分子鎖のすべりなどによる非平衡過程の影餂と

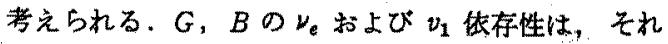
ぞれ次の関係式で記述できるよらである， $G=a(1-$ $\left.v_{1}\right)\left(\nu_{e} k T-b\right), B=B_{0}\left(1-v_{1}\right)-B_{1}$. ここで, aはங் ほとんど影響されず，1 亿近い定数であり，bは灾に 
体存する．また $B_{0} 、 B_{1}$ は它によって定まる定数であ る. $G, B$ は $v_{1}$ K対して共に単調に減少しているが，

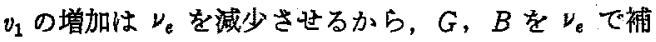
正して $v_{1}$ 依存性を双ると，补依存性は非常心小さい。 Gについては，濃度一時間換算が可能なようである。

Fig. 3(a)に，亡の異なるデータを濃度軸に平行移動し て得られた濃度一時間合成曲線を示した。この重れ合 せのための移動距離 $\alpha_{\mathrm{c}}^{\prime}$ は藤田らの換算式; 一 $(\log$ $\left.a_{s}\right)^{-1}=-\left(\log t-\log t_{s}\right)^{-1}=f\left(v_{1 s}\right)+\left[f\left(v_{1 s}\right)\right]^{2} / r\left(v_{1}-v_{1 s}\right)$ $=f\left(v_{1 s}\right)+\left[f\left(v_{1 s}\right)\right]^{2} / r a_{\mathrm{c}}^{\prime}(3)$ で表わされるよらである

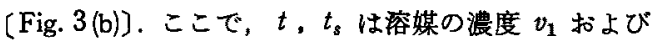
基準濃度 $v_{\boldsymbol{z}}$ に括ける時間尺度を表わす。
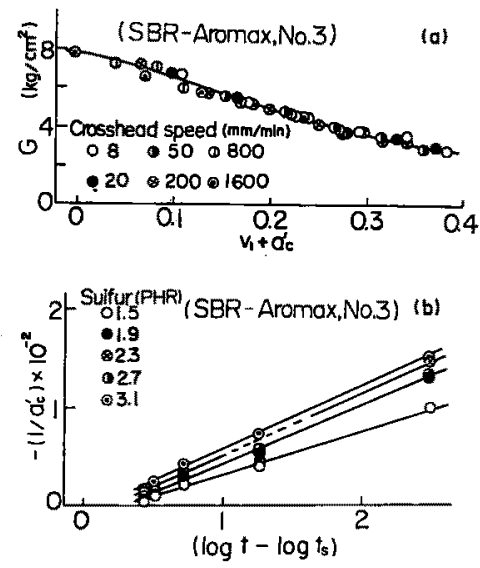

Fig. 3. (a) ; An example of a master curve obtained by superposing $G$ data by applying the method of time-concentration superposition. (b) ; Time dependence of shift distance $a_{c}^{\prime}$ compared with those predicted by Eq. (3).

G，Bに比へ，Cは1/100のオーダであるが，特異 性がみられる.Fig. 2(g)では明らかでないが，㐫が大 きいと，Cは の増加につれて，山の位置は $\nu_{e}$ の小さい方向人移動 し，山の高さも低くなる、またをに対しても山をるつ ようである〔Fig. 2(i)]. Bueche-Dudek らの測定に よれば，加硫ゴムの強度のレeに対する極大の山の存 在は，它に依存するからら, 粘性応力が加わってつくる見 卦けの山であるらが考えられる、Cの

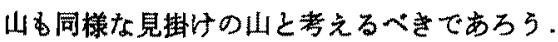

\section{3-2 $\boldsymbol{G}, \boldsymbol{B}, \boldsymbol{C}$ と破壊特性の間の関連}

$3 \cdot 2 \cdot 1$ 破䧇強度 $f_{b}$ との関連 $\dot{\varepsilon}$ 別求めた $f_{b}$ とG，B，Cの相関俰数を Table I に示した， $f_{b}$ と $G ， B$ 相関が高く，予想に反して $f_{b}$ とCの相関は 低かった。それ注，油の配合に上り応力が立ら上がら ず，逆 S字曲線の変曲的付近で破壊がおさているから であろう。この結果から，G，B，Cの $f_{b}$ に対する 奇与は次の上5に考光られる：(1)逆 S字状装力一伸度
Table I. Correlation coefficients obtained for every strain rate.

\begin{tabular}{c|c|c|c}
\hline & $G$ & $B$ & $C$ \\
\hline$f_{b}$ & $0.957 \sim 0.987$ & $0.920 \sim 0.986$ & $0.689 \sim 0.833$ \\
$\begin{array}{c}\text { Fracture } \\
\text { energy } W_{b}\end{array}$ & $0.413 \sim 0.566$ & $0.508 \sim 0.746$ & $0.080 \sim 0.218$ \\
\hline
\end{tabular}

曲線の変曲的付近で切断する加硫ゴムの強度に対する 寄与は， $G ， B か ゙$ 主役であり，このような弱いゴムで は, C 与は小さい，Gが大きく，負項として效く $B$ は小さい 程， $f_{0}$ 性大きくなるであろ5.(2)逆 S 字状曲線の変 曲点を越えて応力が立ち上がる試料については，Cの $f_{b}$ に対する奇与は大きいと期待される。

$3 \cdot 2 \cdot 2$ 破境工ネルギ $\left(\boldsymbol{w}_{b}\right)$ との関連 $w_{b}$ は物 体が破㙘するまでに吸收した外部からの仕事量であ り，特にタフさに関係する量でるる， $G, B, C$ と $w_{b}$ の相関俰数を Table I に示した（2)式の $f$ を真の 張力 $\alpha f$ にした関係から， $w_{b}$ は $w_{b}=G\left\{\left(\alpha_{b}^{3}-1\right) / 3\right.$ $\left.-\log \alpha_{b}\right\}-B\left\{\left(\alpha_{b}^{3}-1\right) / 3-\left(\alpha_{b}^{2}-1\right) / 2+\left(\alpha_{b}-1\right) / \alpha_{b}-\right.$ $\left.\log \alpha_{b}\right\}+C\left\{\left(\alpha_{b}^{5}-1\right) / 5-\left(\alpha_{b}{ }^{3}-1\right) / 3-\left(\alpha_{b}{ }^{2}-1\right) / 2+\log \right.$ $\left.\alpha_{b}\right\}$ となる.Cの項は $\alpha_{b}^{5}$ で効いてくるから，C項は $w_{b}$ に大きく寄与し，相関も高いであろうと予想した が，Cと $w_{b}$ の間の相関は低かった。

\section{4 あとがを}

(2)式の 3 パラィータ式の検楌の目的は, 主にCの举 動を知ることにあったが, 油を変量配合した油展SBR 試料系では，応力が立ち上がらない純 SBR よりさら に強度か減少していくからこの研究の試料としては 適当でなかった，そこで現在は充てん剤補強 SBR を 試料に用い険討中であるが、これはCが大きいよらで ある。

この研究の試料を提供してくださった日本ゼオン (株)開発研究所に深謝申しあげます。

（昭和47年10月18日 第20回レオロジー討㻅会にて講演）

\section{参 考 文 献}

1）挼井正幸，佐藤良泰，永田伸夫，島田晃二，材料，19， 326 (1970).

2）传藤良泰，桜井正幸，清水義雄，材料，21，414（1972）。

3) Wang, M.C., and E. Guth, J. Chem. Phys., 20, 1144 (1952).

4) Isihara, A., N. Hashitsume, and M. Tatibana, J. Chem. Phys., 19, 1508 (1951).

5）佐藤良泰，日本ゴム協会誌に投稿予定，本誌普通号の総

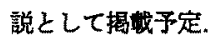

6) Dudek, T. J., and F. Bueche, Rubber Chem. Technol., 37, 818 (1964). 